\title{
Mutagenicity, Creatine and Nutrient Contents of Pan Fried Meat from Various Animal Species
}

\author{
By R. Vikse and P. E. Joner
}

Graduate Research Laboratory, Stabekk College, Bekkestua, and Department of Food Hygiene, Norwegian College of Veterinary Medicine, Oslo, Norway.

\begin{abstract}
Vikse, R. and P.E. Joner: Mutagenicity, creatine and nutrient contents of pan fried meat from various animal species. Acta vet. scand. 1993, 34, 363-370. - The mutagenic activity in extracts of fried meat from 16 different animal species was studied in Salmonella typhimurium TA98. In each experiment, 1 meat sample together with a standard beef sample was fried, and the mutagenicity was expressed relative to the beef sample. All meat samples showed less mutagenic activity than beef. The contents of creatine, creatinine, water, protein, carbohydrate and fat in the meat samples were analyzed, but mutagenicity was not correlated with the concentration of any of these constituents. Beef meat treated with creatinase to remove creatine produced reduced mutagenic activity. Possibly a threshold concentration of creatine is necessary to give a high mutagenic response.
\end{abstract}

cooking mutagens, Ames test, creatinase.

\section{Introduction}

Cooking of proteinaceous food from animal muscle tissue leads to the formation of mutagenic heterocyclic amines. Model studies have shown that creatine and/or creatinine, monosaccharides and free amino acids act as precursors of mutagenic heterocyclic amines, especially the aminoimidazoazaarenes (Jägerstad et al. 1991). Panfrying and baking experiments with bovine tissues and studies on meat flavour products show a relationship between concentration of glucose, monosaccharides, creatine and creatinine in the food stuff and the level of mutagenicity in the prepared product (Laser Reuterswärd et al. 1987a, Laser Reuterswärd et al. 1987b). Addition of creatine to a meat product before frying resulted in greatly increased yields of mutagenic compounds (Nes 1986, Becher et al. 1988).

Other important factors influencing the amount of mutagenic compounds formed are the time of and the temperature during frying (Laser Reuterswärd et al. 1987b) and the water (Bjeldanes et al. 1983) and fat content of the food stuff (Spingarn et al. 1981).

Marked progess has been done in understanding the conditions for the formation of mutagenic heterocyclic amines (Jägerstad et al. 1991). Still much work needs to be done regarding factors that might influence the yields of mutagenic amines formed in cooked foods. Most of the cooking experiments with meat and offal has been performed with bovine and pork tissues (Berg et al. 1990, Laser Reuterswärd et al. 1987b). However fried meat other than beef and pork are frequently consumed. The purpose of the work was to study the yields of cooking mutagens produced in meats from different animal species. The mutagenic 
yield was quantified by exposing Salmonella typhimurium to extracts from the cooked product in the presence of a metabolizing system. The results have been analyzed for a possible correlation between mutagenic activity and the contents of total protein, carbohydrate, fat, water, creatine and creatinine.

Digestion of finely ground muscle with creatinase reduces the creatine content. We have also studied the effect of such partial removal of creatine from beef on the yields of mutagenic activity after cooking.

\section{Material and methods \\ Chemicals}

Aroclor 1254 was purchased from Chem Service, (West Chester, Pa., USA); ATP*; Benzo(a)pyrene B(a)P; Creatinase; DL-Dithiothreitol; Glucose-6-phosphate; Lactatedehydrogenase (EC 1.1.1.27); Pyruvate kinase (EC 2.7.1.40); NADP; NADH; Phosphoenolpyruvate; Sodium orthovanadate; from Sigma Chemical Co. (St. Louis, MO, USA) and Creatininase (EC 3.5.2.10) from Boehringer Mannheim GmbH (Germany). All other chemicals and bacteriological media were of best quality from standard sources.

\section{The pan frying procedure}

Fresh or freshly frozen meat was bought at the local supermarket. The meat free from visible fat and connective tissue, was minced and fried without any additives. Fresh beef from a common shoulder sample from a single ani-

Abbreviations: ATP, Adenosine 5'-Triphosphate; DMSO, dimethyl sulphoxide; MeIQx, (2-amino-3, 8dimethyl-3H-imidazo[4,5-f]quinoxaline; NADH, nicotinamide adenine dinucleotıde reduced form; NADP, nicotinamide adenine dinucleotıde phosphate. mal was used in all the comparative frying experiments as a standard. In the experiments studying the influence of creatinase digestion on the production of cooking mutagens during pan frying beef meat from the leg (3 different animals) was used. The following experimental conditions were maintained to ensure equal treatment of all meat samples during frying: In each experiment two $50 \mathrm{~g}$ portions of minced beef and two $50 \mathrm{~g}$ portions of minced meat from another animal were formed into patties, $7 \mathrm{~cm}$ in diameter. They were placed on a metal plate in 4 separate metal cylinders, to keep the meat separated and to aid transfer into the pan simultaneously. A teflon coated frying pan on a standard hot plate was used for frying. The frying pan was lightly greased with maize oil. The temperature in the frying pan was measured with a termocouple (Digitron, $-50+750^{\circ} \mathrm{C}$ ), and when the temperature reached $250^{\circ} \mathrm{C}$ all 4 pieces of meat patties were transferred into the pan at the same time. To ensure optimal contact between the meat and the hot surface of the frying pan, a lid weighing $400 \mathrm{~g}$ was applied on top of the patties. To compensate for possible uneven heating by the plate the pan was rotated 4 times during the 12 min frying period (6 min on each side). The frying was performed with the same hot plate setting each time. The meat was lightly charred.

\section{Extraction and fractionation}

The meat crust was freed from the core material with a soft knife and the mutagenic basic organic components were extracted according to the method of Felton et al. (1981): The crust was homogenized in acetone (Ultrathorax, Inter Med, Disp 25, Roskilde, Denmark) and filtered through a sintered glass funnel. The extract was cooled to $-18^{\circ} \mathrm{C}$ overnight and then filtered through a Whatman No. 1 filter and concentrated on a rotary evaporator to near 
dryness. The filtrate was diluted in $0,01 \mathrm{~N} \mathrm{HCl}$ and extracted 3 times with $\mathrm{CH}_{2} \mathrm{Cl}_{2}$. The $\mathrm{pH}$ of the aqueous phase was adjusted to $\mathrm{pH} 12$ and again extracted 3 times with $\mathrm{CH}_{2} \mathrm{Cl}_{2}$ to obtain the basic components This basic extract was concentrated to near dryness on a rotary evaporator and dried under a stream of nitrogen gas. For mutagenicty testing the residues were dissolved in dimethyl sulphoxide (DMSO).

\section{Mutation Assay}

Mutagenicity was determined with Salmonella Typhimurium TA98 and enzymatic activation (S9) as described by Maron \& Ames (1983), and measured in triplicate with $20 \mathrm{ml}$ agar per dish.

Dose-response curves in these experiments are assumed to be linear, and the values are therefore based on single dose measurements. The S9 liver-extract was prepared from Aroclor treated rats and the amount of protein per dish was $2 \mathrm{mg}$. The bacterial strain Salmonella thypimurium TA 98, was provided by Dr. Bruce Ames, University of California. Benzo(a)pyrene was used as positive control. The mean number of spontaneous revertants was $39(\mathrm{SD} \pm 9)$ during the experimental period and this value was subtracted from the results shown.

\section{Creatine/Creatinine Analysis}

Creatine and creatinine were extracted from meat samples, and measured according to methods described by Wahlefeldt \& Siedel (1985) with some modifications.

The essay was performed in a $0.2 \mathrm{M}$ glycine/KOH buffer $\mathrm{pH} 8.0$ containing the following compounds: Glycine, $154 \mathrm{mM}$; Dithiothreitol, $1.5 \mathrm{mM} ; \mathrm{MgCl}_{2}, 23 \mathrm{mM}$; ATP, 1.0 $\mathrm{mM}$; NADH, $0.35 \mathrm{mM}$; Phosphoenolpyruvate, $1.0 \mathrm{mM}$; Pyruvate kinase, $19 \mathrm{kU} / \mathrm{l}$; Lactate-dehydrogenase, $10 \mathrm{kU} / 1$ and Creatini- nase, $7 \mathrm{kU} / \mathrm{l}$. A crude preparation of Creatine kinase (EC 2.7.3.2.), prepared from rabbit muscle (Keutel et al. 1972; Kuby et al. 1954), was added in adequate amounts. This enzyme preparation was found more suitable than the commercial one. Sodium orthovanadate was added to a final concentration of $0.38 \mathrm{mM}$, in order to minimize ATP-ase activity in the creatine kinase preparation. The measurement was performed in a Hewlett Packard 8452A diode array spectrophotometer at 340 $\mathrm{nM}$ and standards were always included.

\section{Creatinase treatment of meat}

$50 \mathrm{~g}$ minced meat was homogenized for $2 \mathrm{~min}$ in $45 \mathrm{ml} 0.1 \mathrm{M} \mathrm{KCl}$ (Ultrathorax). The $\mathrm{pH}$ was adjusted to 7.5 with $1 \mathrm{M}$ Tris base. $1000 \mathrm{U}$ Creatinase was added and the mixture was incubated for 2 or $2.5 \mathrm{~h}$ at $37^{\circ} \mathrm{C}$ in a water bath. The total volume of added liquid was $50 \mathrm{ml}$. Another $50 \mathrm{~g}$ portion of meat was similarly treated but in the absence of enzyme. After incubation, $10 \%$ potato starch was added to give the product a suitable texture for frying. Four portions of this dough, 2 with and 2 without enzyme, each weighing $50 \mathrm{~g}$ were fried simultanously as described. The meat crust in 2 experiments and both the crust and core in 1 experiment were extracted and fractionated as described.

\section{Food analysis}

The content of fat, glucose, nitrogen and water in the meat were performed according to the methods of Nordic committee on food analysis. (Anon. 1974 a, b; 1976; 1978).

\section{Results}

In the present study, we measured the mutagenic activity extracted from the frying crust of minced meat samples from 16 different animal species in the Ames Salmonella test. The 
Relative mutagenicity

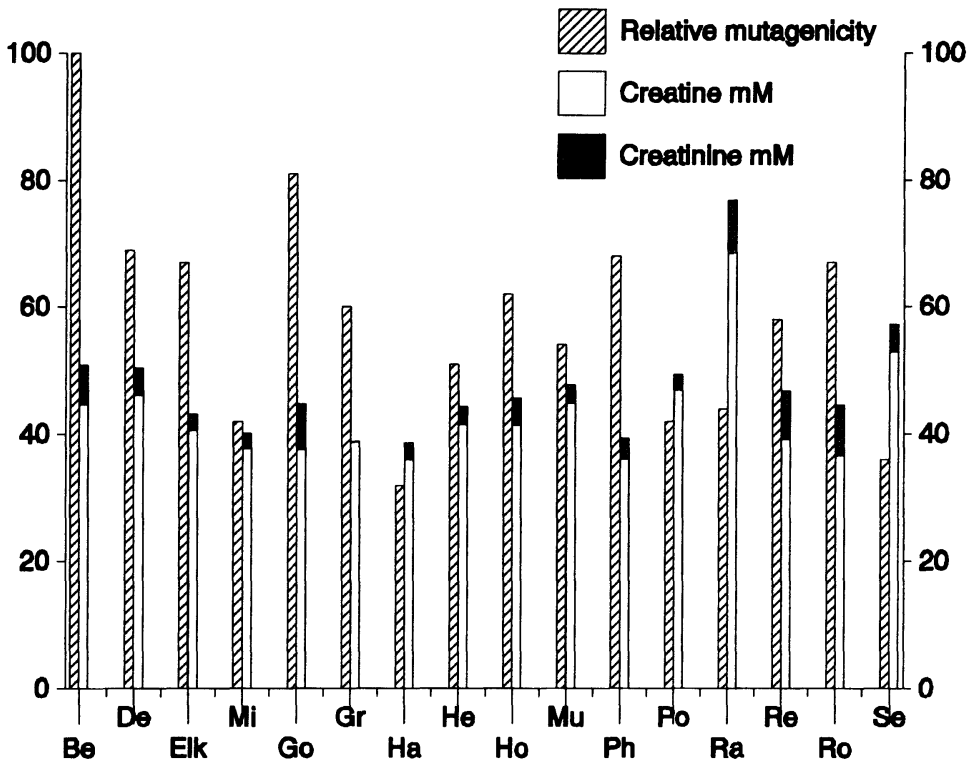

Figure 1. Relative mutagenicity in frying crusts of meat samples from 16 different animal species, compared to the concentration of creatine and creatınıne in samples from the same animals. Mutagenicity was determined by the Ames/Salmonella test and related to the mutagenicity of the beef sample fried in the same experiment, which was set to 100 percent. Creatine and creatınine content were determined in uncooked meat. Abbreviatıons: $\mathrm{Be}=$ beef; $\mathrm{De}=$ deer; $\mathrm{Mi}=$ minced elk; $\mathrm{Go}=\mathrm{Goat} ; \mathrm{Gr}=$ grouse; $\mathrm{Ha}=$ hare; $\mathrm{He}=$ hen; $\mathrm{Ho}=$ horse*; $\mathrm{Mu}$ $=$ mutton; $\mathrm{Ph}=$ pheasant; $\mathrm{Po}=$ pork $\mathrm{Ra}=$ rabbit $\mathrm{Re}=$ reindeer*; $\mathrm{Ro}=$ roe-deer*; $\mathrm{Se}=$ seal ${ }^{*}$. The results represent the mean value from two identical meat portions fried in the same experıment, except for the species labelled *, where 2 independent experiments were performed. Creatine and creatinine values represent mean of 2 independent experiments. B(a)P as positive control ( $5 \mu \mathrm{g} / \mathrm{d}$ ssh) gave $482 \pm 168$ revertants/dish troughout the study.

results are expressed as percent of the activity extracted from the standard beef samples fried in the same experiment (Fig. 1). In all experiments the common reference sample of beef contained the highest mutagenic activity. Of the other meat products seal gave the lowest score (36\% of the standard beef) and goat the highest ( $81 \%$ of standard). The absolute values as Salmonella typhimurium TA98 revertants $/ 100 \mathrm{~g}$ raw meat are presented in Table 1 , accompanied by the values obtained with the standard beef sample that day. The average number of $S$. typhimurium revertants was $30608 \pm 6594(n=15)$, expressed per 100 $\mathrm{g}$ raw beef.

In Table 2 the content of water, fat, protein and carbohydrate in the 16 different meat samples are presented. The minced elk sample is a commercial meat product that contains $8.8 \%$ fat. The correlation coefficients between mutagenicity, and the content of water, fat, protein or carbohydrate were calculated by linear regression to $R=-0.265$, $-0.045,-0.352,-0.313$, respectively. 
Table 1. Mutagenicity in frying crusts (TA98 revertrants $/ 100 \mathrm{~g}$ raw meat) $\dagger$.

\begin{tabular}{lrc}
\hline Anımal & Meat & Beef \\
\hline Deer & 12140 & 17540 \\
Elk & 23640 & 35300 \\
Elk, mince & 9560 & 22740 \\
Goat & 30420 & 37460 \\
Grouse & 19840 & 32940 \\
Hare & 11260 & 35200 \\
Hen & 20200 & 39860 \\
Horse & 17180 & 27600 \\
Mutton & 15940 & 29460 \\
Pheasant & 22480 & 32960 \\
Pork & 15040 & 36200 \\
Rabbit & 12080 & 27280 \\
Reindeer & 21260 & 37090 \\
Roe-deer & 15610 & 23200 \\
Seal & 8630 & 24290 \\
\hline
\end{tabular}

$\dagger$ The table presents the mutagenicity of the different meat extracts together with the standard beef sample fried in the same experiment.

The concentration of creatine and creatinine in the raw meat samples are included in Fig. 1. Creatinine concentration is much lower than the creatine concentration in all meat samples, pork has the lowest concentration with $2,5 \mathrm{mM}$ and rabbit the highest with $8,3 \mathrm{mM}$. Creatine concentration is lowest in hare with $36 \mathrm{mM}$ and highest in rabbit with $69 \mathrm{mM}$. The correlation coefficient between mutagenicity and meat content of creatine and creatinine was calculated to $\mathrm{R}=-0.138$.

In Fig. 2 the effect of creatinase treatment of beef meat on the extractable mutagenic activity in fried patties is presented, in relation to the creatine and creatinine contents in the meat before frying. The average decrease in creatine concentration was $65 \%$ which resulted in $73 \%$ average decrease in the mutagenic response from the meat ectract.
Table 2. Content of water, fat, protein and carbohydrate in 16 meat samples from different species (percent) $* *$.

\begin{tabular}{lcccc}
\hline Anımal & Water & Fat & Protein & Carbohydrate \\
\hline Beef & 74,1 & 5,1 & 20,5 & 0,1 \\
Deer & 70,5 & 2,0 & 24,8 & 0,2 \\
Elk & 74,4 & 1,8 & 23,1 & n.d. \\
Elk, mince & 69,8 & 8,8 & 21,4 & n.d. \\
Goat & 79,2 & 1,6 & 20,0 & 0,7 \\
Grouse & 70,5 & 2,0 & 24,6 & n.d. \\
Hare & 76,2 & 1,5 & 21,8 & 0,2 \\
Hen & 73,4 & 3,0 & 23,9 & n.d. \\
Horse & 74,3 & 4,0 & 21,3 & 0,6 \\
Mutton & 74,2 & 3,3 & 22,9 & n.d. \\
Pheasant & 74,0 & 1,4 & 24,1 & n.d. \\
Pork & 75,1 & 1,3 & 22,3 & n.d. \\
Rabbit & 73,2 & 1,8 & 24,2 & 0,2 \\
Reindeer & 71,6 & 1,9 & 27,3 & n.d. \\
Roe-deer & 74,0 & 1,8 & 23,0 & 0,2 \\
Seal & 70,5 & 2,0 & 27,3 & n.d. \\
\hline
\end{tabular}

* The analysis were performed according to the methods of Nordic committee on food analysis. n.d. $=$ not detected.

\section{Discussion}

The total mass amount of mutagens formed during cooking of meat is influenced by cooking temperature and time (Berg et al. 1990, Dolora et al. 1979, Felton \& Knize 1991, Laser Reuterswärd et al. 1987b). Our mutagenicity value of 30608 revertants $/ 100 \mathrm{~g}$ initial raw weight for beef is higher than results from other studies, where 6300-23500 revertants per $100 \mathrm{~g}$ raw weight were obtained for beef patties fried at $200^{\circ} \mathrm{C}$ for 3-12 minutes (Bjeldanes et al. 1982, Commoner et al. 1978, Felton et al. 1981, Laser Reuterswärd et al. 1987b). Interlaboratory variation could also be attributed to variability in the Ames test, in the activity of the S9 preparation, in the source of meat or cooking procedure used (Felton et al. 1981). 
TA98 revertants per dish

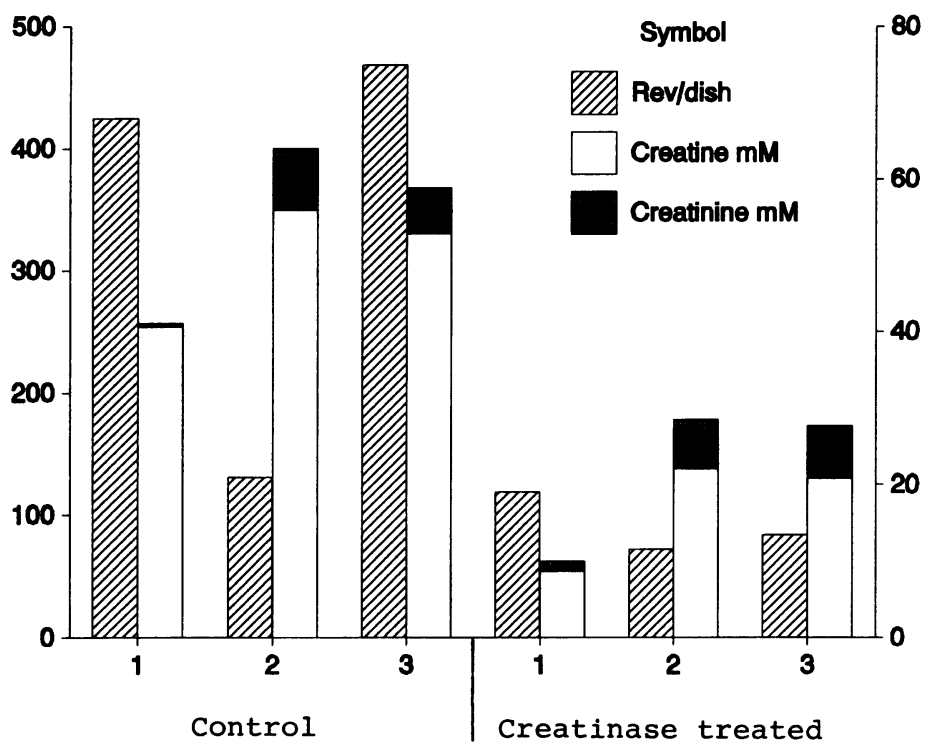

Figure 2. Mutagenicity in extract from fried minced beef treated with creatınase, expressed as Salmonella revertants per dish and creatine and creatinine concentration determined in the uncooked samples. Results from three different experiments with controls are shown. In experiment 1 and 2 mutagens from the crust were extracted, in experiment 3 mutagens from the core and crust were extracted. MeIQx (2-amıno-3, 8-dimethyl-3Himıdazo[4,5-f]quinoxaline as positive control gave $67341 \pm 8730$ revertants $/ \mu \mathrm{g}(\mathrm{n}=3)$.

We preferred to cook our meat at a somewhat higher temperature than normally used in the household, to ensure an efficient induction of mutagenic activity in the fried meat patties. Otherwise the cooking conditions and equipment were similar to those normally used in the household. Felton et al. (1988) have shown that the same set of mutagenic compounds is produced in meat cooked at $200^{\circ} \mathrm{C}$ and at $300^{\circ} \mathrm{C}$. Care was taken to fry all meat samples under identical conditions, but because of the variability between experiments we decided to express the mutagenicity of the different meat samples relative to a beef sample that was included in all experiments.

The water, fat, protein and carbohydrate con- tent of the different types of meat used in these experiments did not correlate with mutagenic activity produced during cooking.

Several reports have shown that addition of creatine to meat before frying greatly increases the mutagenic activity produced (Nes 1986, Becher et al. 1988). However, differences in the normal creatine and creatinine content of the meat studied here, do not seem to explain the varying mutagenic response from extracts of the fried meat.

It is known from the literature that when fish is prepared and cooked in the same way as beef, a much lower mutagenic activity is produced (Felton \& Knize 1991). We measured the creatine and creatinine concentrations in 
cod to 39 and 0,6 $\mathrm{mM}$, respectively, and these values are very similar to the content of these substances in beef.

Fig. 1 demonstrates that creatine and creatinine concentrations differ considerably between the meat samples from the various species analyzed in this experiment, and they are both lower and higher than the concentrations found in the standard beef sample.

The creatinase experiments of Fig. 2, confirm the suggested relationship between creatine concentration and mutagenicity. However, even if creatine/creatinine are important parameters in mutagen formation, the relationship is not a simple one. This is shown by the lack of correlation between creatine/creatinine content and mutagenicity in Fig. 1. The result of the creatinase experiment also suggests that if a workable procedure could be found for removal of creatine from animal tissues, reduced content of cooking mutagens might be achieved. However, the levels of creatine and creatinine in our meat preparations are after creatinase treatment almost at the same level as that found in bovine heart and tongue samples, as reported by Laser Reuterswärd et al. (1987b). These authors found heart and tongue to contain higher mutagenic activity than muscle when fried under identical conditions. They argued that a possible explanation may be that the relative concentrations of creatine and free amino acids versus dipeptides and monosaccharides in heart and tongue, are different from those in muscle, where the concentrations of creatine, free amino acids and dipeptides are almost equimolar (Laser Reuterswärd et al. 1987b). Both in cooked foods and in model systems creatinine is still present after heating, and only a small part is used in the reaction (Laser Reuterswärd et al. 1987b, Skog \& Jägerstad 1990). According to Jägerstad et al. (1991) creatinine is an essential precursor in mut- agen formation, but its concentration seems not to be a yield limiting factor.

Our results suggest that in meat a certain threshold concentration of creatine is necessary to produce a high mutagenic response. Within the normal concentration range found in the different meats studied, however, there seems to be no correlation between creatine concentration and mutagenicity.

\section{Acknowledgements}

We thank Siri Mathiesen and Anne Holm for excellent technical assistance. Salmonella typhimurium strain TA98 was kindly provided by Professor Bruce Ames, University of Calıfornia (Berkeley, CA, USA).

Financial support from the Agricultural Research Council of Norway, Stabekk College and Gudrun Akre's foundation is gratefully acknowledged. We gratefully acknowledge the advice and criticism we received from professor Leiv Klungsøyr, Stabekk College, throughout this work.

\section{References}

Anonymous:

Nordic committee on food analysis. Fat Determination in Meat and Meat products according to SBR Schmid-Bondzynskı-Ratslaff. 1974 a, No 88.

Nordic committee on food analysis. Moisture and Ash determination in meat and meat products. 1974 b, No 23.

Nordic committee on food analysis. Nitrogen Determination in foods and feeds according to Kjeldahl. 1976, No 6.

Nordic committee on food analysis. Glucose Determination of the total amount in meat products after hydrolysis. 1978, No 93.

Becher G, Knize MG, Nes IF, Felton JS: Isolation and identification of mutagens from a fried Norwegian meat product. Carcinogenesis 1988, 9, 247-253.

Berg I, Övervık E, Gustafsson J-Å: Effect of cooking time on mutagen formation in smoke, crust and pan residue from pan-broiled pork. Fd. Chem. Toxic. 1990, 28, 421-426.

Bjeldanes LF, Grose KG, Davis PH, Stuermer DH, Healy SK, Felton JS: An XAD-2 resin method 
for efficient extraction of mutagens from fried beef. Mutation Res. 1982, 105, 43-49.

Bjeldanes LF, Felton JS, Hatch FT. Mutagens in cooked food. In: Finley JW, Schwass DE (eds.): Xenobiotics in foods and feeds. American Chemical Society, Washington 1983, pp. 149-167.

Commoner B, Vithayathil A, Dolora P: Mutagenic analysis as a means of detectıng carcinogens in foods. J. Food. Protect. 1978, 41, 996-1003.

Dolora P, Commoner B, Vithayathil A, Guca G, Tuely E, Madyastha P, Nair S, Kriebel D: The effect of temperature on the formation of mutagens in heated beef stock and cooked ground beef. Mutation Res. 1979, 60, 231-237.

Felton JS, Healy S, Stuermer D, Berry C, Timourian $H$, Hatch FT, Morris M, Bjeldanes LF: Mutagens from the cooking of food 1 . Improved extraction and characterization of mutagenic fractions from cooked ground beef. Mutation Res. 1981, 88, 3344.

Felton JS, Knize MG, Shen NH, Wu R, Becher G: Mutagenıc heterocyclic imidazoamines in food. In: King CM, Romano LJ, Schuetzle D (eds.): Carcinogenic and mutagenic responses to aromatic amines and nitroarenes. Elsevier, London, 1988, pp. 73-85.

Felton JS, Knize $M G \cdot$ Occurrence, Identification and bacterial mutagenicity of heterocyclic amines in cooked food. Mutation Res. 1991, 259, 205-217.

Jägerstad M, Skog K, Grivas S, Olsson K: Formation of heterocyclic amines using model systems. Mutation Res. 1991, 259, 219-233.

Keutel HJ, Okabe K, Kacobs HK, Ziter F, Maland L, Kuby SA: Studies on adenosine triphosphate transphosphorylases. Arch. B1ochem. 1972, 150, 648-678.

Kuby SA, Noda L, Lardy HA: Adenoseinetriphosphatecreatıne transphosphorylases 1 . Isolation of the crystalline enzyme from rabbit muscle. J. Biol. Chem. 1954, 209, 191-201.

Laser Reutersward A, Skog K, Jagerstad M• Effects of creatine and creatinine content on the mutagenic activity of meat extracts, bouillons and gravies from different sources. Fd. Chem. Toxic. 1987 a, 25, 747-754.
Laser Reutersward A, Skog K, Jagerstad M: Mutagenicity of pan-fried bovine tissue in relation to their content of creatine, creatinine, monosaccharides and free amino acids. Fd. Chem. Toxic. 1987 b, 25, 755-762.

Maron DM, Ames BN: Revised methods for the Salmonella mutagenicity test. Mutation Res. 1983, 113, 173-215.

Nes IF: Mutagen formation in fried meat emulsion containing various amounts of creatine. Mutation Res. 1986, 175, 145-148.

Skog K, Jagerstad M: Effects of monosaccharides and disaccharides on the formation of food mutagens in model systems. Mutation Res. 1990, 230, 263-272.

Spingarn NE, Garvie-Gould C, Voulo LL, Lund DB: Formation of mutagens in cooked foods. Cancer Lett. 1981, 12, 93-97.

Wahlefeldt AW, Siedel J: Creatıne and creatınıne. In: Bergmeyer HU (ed.). Methods of enzymatic analysıs, Metabolites 3: Lipids, amıno acids and related compounds, $\mathrm{VCH}$ Verlagsgesellschaft GmbH, Germany, 1985, pp, 488-507.

\section{Sammendrag}

Innhold av stekemutagener kreatın, kreatinin og naringsstoffer $\imath$ ulıke typer av stekt $k\rfloor \phi t t$.

I stekeskorpen på kjøtt dannes det mutagene aromatiske heterosykliske amıner. $\mathrm{V}_{1}$ har stekt kjøttkaker fra 16 ulıke kృøttslag og målt den mutagene aktıviteten 1 ekstrakt fra stekeskorpen med Ames' test. I hvert eksperiment ble to kjøttkaker stekt sammen med to standard kjøttkaker av okse, og mutagenisiteten er uttrykt relatıvt 1 forhold til okse. Alle kjøttprøvene gav noe lavere mutagen aktivitet enn okse. Det var ingen korrelasjon mellom mutagenıs1tet og kjøttprøvenes innhold av kreatın, kreatının, vann, protein, karbohydrat og fett. Oksekjøtt behandlet med kreatinase gav redusert mutagen effekt. Det er mulıg at et visst mınimumsnivå av kreatın er nødvendig for å få høy mutagen aktivitet i stekeskorpe fra kjøtt.

(Recelved January 10, 1993; accepted June, 1993).

Reprints may be requested from: R. Vikse, Graduate Research Laboratory, Stabekk College, Ringstabekkveien 105, N-1340 Bekkestua, Norway. 